Review Article

\title{
Moringa oleifera is a Prominent Source of Nutrients with Potential Health Benefits
}

\author{
Zahidul Islam (D), S. M. Rashadul Islam (D), Faruk Hossen (D), Kazi Mahtab-ul-Islam (D), \\ Md. Rakibul Hasan $(1)$, and Rezaul Karim \\ Bangladesh Council of Scientific and Industrial Research (BCSIR), Dhaka 1205, Bangladesh \\ Correspondence should be addressed to Rezaul Karim; rezaul.karim.saml@gmail.com
}

Received 16 March 2021; Accepted 22 July 2021; Published 11 August 2021

Academic Editor: Zheng-Fei Yan

Copyright (c) 2021 Zahidul Islam et al. This is an open access article distributed under the Creative Commons Attribution License, which permits unrestricted use, distribution, and reproduction in any medium, provided the original work is properly cited.

\begin{abstract}
Nowadays, the socioeconomic status has been changed a lot, so people are now more concerned about their life style and health. They have knowledge about the detrimental effects of synthetic products. That is why they are interested in natural products. Utilization of natural products of plant origin having fewer side effects has gained popularity over the years. There is immense scope for natural products that can intimate health benefits beyond traditional nutrients. Moringa oleifera is one such tree having tremendous nutritional and medicinal benefits. It is rich in macro- and micronutrients and other bioactive compounds which are important for normal functioning of the body and prevention of certain diseases. Leaves, flowers, seeds, and almost all parts of this tree are edible and have immense therapeutic properties including antidiabetic, anticancer, antiulcer, antimicrobial, and antioxidant. Most of the recent studies suggested that Moringa should be used as a functional ingredient in food. The aim of this review is to focus the use of Moringa oleifera as a potential ingredient in food products.
\end{abstract}

\section{Introduction}

In the context of global vision, one of the very first millennium development goals (steps to eradicate extreme hunger and poverty) is to "reduce by half the proportion of children that are malnourished (MDG)." Food deprivation is typically termed as hunger where malnutrition is something else. Malnutrition refers lack of quality food which is insufficient to support proper development and health. According to the report of the hunger project, in November 2017, 815 million people do not have food to sustain themselves out of 7.6 billion people of the world (Know Your World, The World Hunger Project). Moreover the exponential population growth threatens the margins of food security as time progresses. According to a report by the UN's Food and Agriculture Organization, earth is capable of ensuring the food security, where the agricultural sector needs a major transformation to reach its full potential [1]. Moringa oleifera, a native species of the Indian subcontinent, is a fast growing drought-resistant tree belonging to the family Moringaceae [2]. It is widely cultivated for the diversified use of its young seed pods and green leaves as vegetables and for medicine. It is considered as a very good supplement because of its high protein value. Without that, it is known as the miracle tree because of its diversified beneficial features, e.g., 10 times more vitamins than carrots, 7 times more vitamin $C$ than oranges, 17 times more calcium than milk, and 15 times more potassium than bananas [3]. In addition, it helps to increase the blood antioxidant level [4] and reduce the blood sugar level [5] and sustained inflammation [6]. Figure 1 summarize a common scenario about global Moringa leaf powder market demand which is expected to exceed USD 6 billion up to 2025 on account of increasing demand in the dietary supplement and food applications [7].

Most of the production and international trade of $M$. oleifera comes from India, in canned produce, fresh fruits, oil, seeds, and leaf powder [8]. India has an annual production of 1.1-1.3 million tons of tender pods [9]. According to Zauba.com, India exported Moringa leaf powder worth USD $4,746,132$, equivalent to $836,806 \mathrm{~kg}$ for the period June 2013 up to July 2015. Of the total amount, the United States is the largest single buyer of Moringa leaf powder accounting 


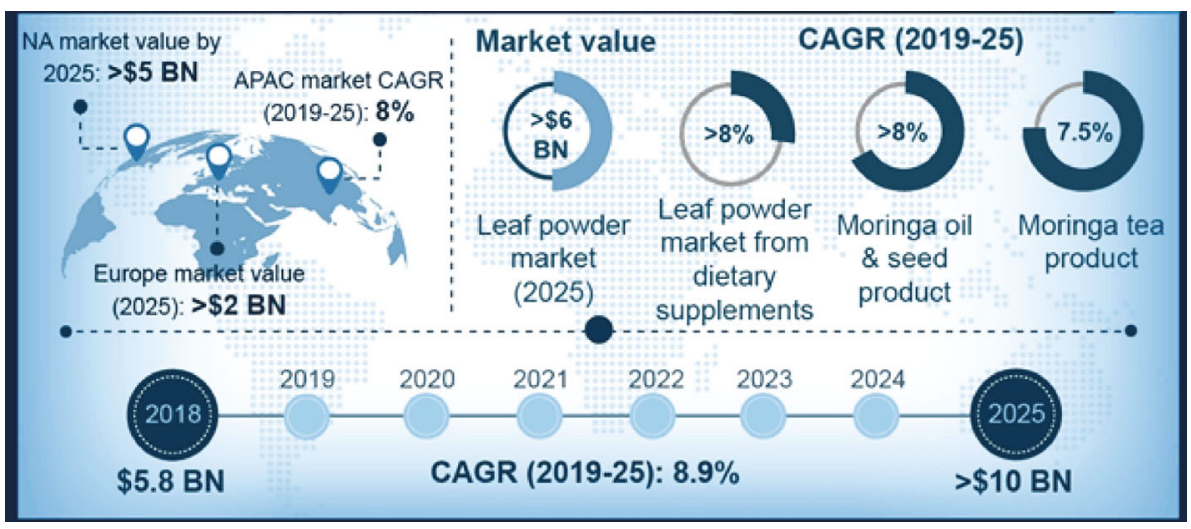

FIGURE 1: Moringa ingredient market.

for USD 3,303,870 followed by Germany and the United Kingdom which imported Moringa leaf powder worth USD 364,170 and USD 162,365, respectively. Netherlands imported Moringa leaf powder worth USD 12,594 over the same period [10]. On the other hand Moringa oleifera is not a crop of commercial interest in Bangladesh. Only consumption of pods is popular, and other uses such as leaves and flower consumption remain minimal. To improve the acceptability among the native people and the foreign market, different government and NGOs should come forward to explore the opportunities for export of Moringa. Figure 2 illustrates the market diagram of Moringa-derived products and future opportunities in Bangladesh [11].

This study emphasizes on the importance of Moringa oleifera in food and nutraceutical industry and how it can assist in improving the health and well-being of humans. It focuses on the current status of Moringa oleifera as human food supplementation and future prospective.

1.1. Variety of Moringa Species and Its Geographical Distribution. The species Moringa is popular from the very ancient times because of its traditional use as a health curing agent and food as nutritionally enriched [12]. The single genus Moringa consists of 14 species [13] and 13 species that have been widely distributed and naturalized in Bangladesh, Sri Lanka, Pakistan, Arabian region, Africa, West Indies, Florida, South America, Peru, Paraguay, and Brazil [14] which is depicted in Table 1. M. oleifera is the most widely known and utilized of these [13]. The species of Moringa can be categorized into three groups on the basis of its trunk types [15].

The species from the plant list is taxonomically validated (http://www.theplantlist.org, v1.1, 2013). Among all these species, Moringa oleifera (Native in India and Bangladesh) has been cultivated in many countries of the world apart from the Pacific Islands, the Caribbean, Latin America, and Asia [14]. On the basis of the availability, Moringa oleifera was specified for this study for the clearance of specialty over other Moringa species. So much research has been done on this species (Moringa oleifera) since the 1970s [16]. Presently, the nutritional and medicinal importance is known to all.

1.2. Why Is Moringa known as the Miracle Tree? The Moringa tree grows quickly, and they grow from seeds or cut- tings of branch of trees. The tree leaves are something more than amazing though they grow quickly in poor soil within a very short period. Moreover, the tree is sustainable at dry and hot climates and is resistant to drought. The leaves, fruits, flowers, and immature pods of this tree are edible, and they form a part of traditional diets in many countries of the tropics and subtropics $[17,18]$. Moringa is rich in nutrition owing to the presence of a variety of essential phytochemicals present in its leaves, pods, and seeds. In fact, Moringa is said to provide 7 times more vitamin $\mathrm{C}$ than oranges, 10 times more vitamin A than carrots, 17 times more calcium than milk, 9 times more protein than yoghurt, 15 times more potassium than bananas, and 25 times more iron than spinach [3]. The small leaves of Moringa pack a full punch of nutrients which contain more protein than eggs, more iron than spinach, more vitamin A than carrots, and more calcium than milk. The Moringa plant is found as a good source of energy with potential as pharmaceuticals and cosmetics (oils from seeds for hair and skin care) benefits. Moringa seeds are also rich in vitamins and minerals. Seed extracts show antibacterial activity and are also used as a water purifying agent. Various studies found Moringa seeds as oxidative stress-, inflammation-, blood sugar-, and blood pressure-reducing agents. People suffering from malnutrition and poverty found Moringa as a superfood because of its nutritional alternatives.

1.3. Food and Supplementation from Moringa oleifera. In the recent world, people are conscious but compelled to take calorific foods due to their busy schedule. Such food habits result in various health-related problems such as obesity, high blood pressure, diabetes, and various chronic diseases. For a balanced life style, a proper diet with an optimum level of vitamins, minerals, and PUFAs, etc. is required.

Moringa leaves are known as a very good food source which is easily digestible and rich in proteins [14]. According to Sultana and Anwar [19], Moringa leaves possess many valued compounds such as protein, vitamin, calcium, iron, ascorbic acid, and antioxidants (carotenoids, flavonoids, and phenol). Different developing or underdeveloped countries of the world feed their children with Moringa [20]. Busani et al. reported that the presence of numerous minerals and vitamins helps to improve the immunity against various 


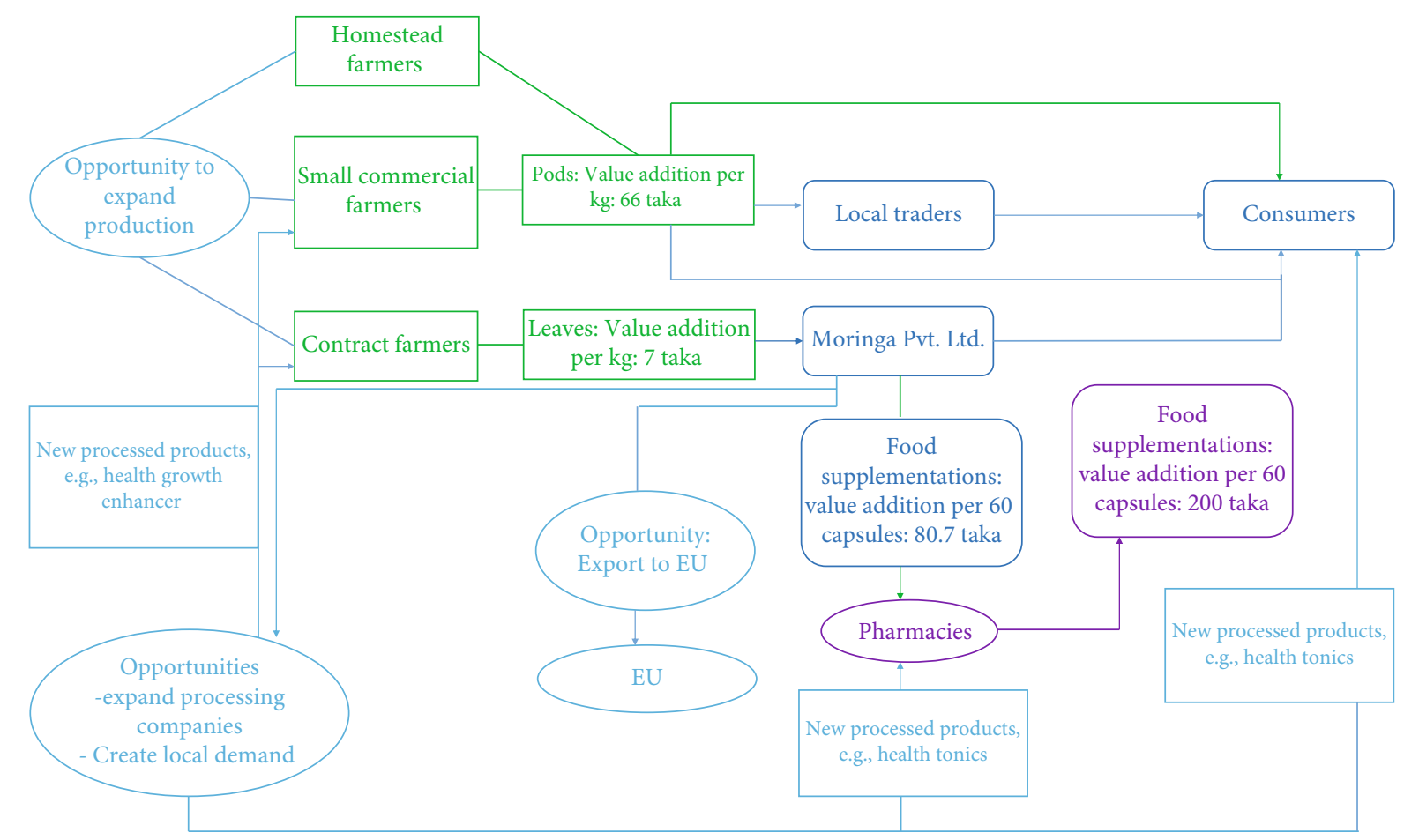

FIgURE 2: Market map of the current value chain and future opportunities in Bangladesh.

TABle 1: Categories of Moringa spp.

\begin{tabular}{|c|c|c|c|}
\hline Category no. & Species & Categorization on the basis of trunk types & Geographical availability \\
\hline \multirow{4}{*}{1} & Moringa stenopetala & \multirow{4}{*}{ Bottle tress (bloated water-storing trunks) } & Kenya, Southwest Ethiopia, Somalia \\
\hline & Moringa drouhardii & & Southern Madagascar \\
\hline & Moringa ovalifolia & & Namibia, Southwest Angola \\
\hline & Moringa hildebrandtii & & Southern Madagascar \\
\hline \multirow{3}{*}{2} & Moringa peregrina & \multirow{3}{*}{ Slender trunks } & Red Sea, Arabia, Northeast Africa \\
\hline & Moringa concanensis & & India \\
\hline & Moringa oleifera & & India \\
\hline \multirow{6}{*}{3} & Moringa borziana & \multirow{6}{*}{ Tuberous shrubs } & Kenya, Somalia \\
\hline & Moringa arborea & & Kenya, Somalia \\
\hline & Moringa longituba & & Kenya, Southeast Ethiopia, Somalia \\
\hline & Moringa pygmaea & & North Somalia \\
\hline & Moringa rivae & & Kenya, Ethiopia \\
\hline & Moringa ruspoliana & & Kenya, Ethiopia, Somalia \\
\hline
\end{tabular}

diseases [21]. Moreover, Moringa leaves contain various amino acids. But nutrient variation is common because of climatic, location, and environmental factors [22]. Nowadays, Moringa leaves have diversified uses, such as medicinal coated capsules (as powder), as drinks (Ziga drinks), and tea [23]. Because of its nutritional properties, it is known as the miracle tree. Table 2 depicts proximate profiles of Moringa fresh leaves, dry leaves, and leaf powder [24, 25].

1.4. Proteins and Amino Acids. Protein is an essential macronutrient for the human body responsible for overall growth, which is also known as a building block unit. Moringa leaves contain diversified phytochemicals such as sterols, tannins, flavonoids, alkaloids, saponins, and terpenoids [26]. Protein can be defined as a combination of long chain essential and nonessential amino acids which are linked by a peptide bond [27]. The essential amino acids need to be supplied externally as food items, whereas the nonessential amino acids can be produced by the body itself. Eggs, poultry meat, fish, red meat, etc. are known as common source of essential amino acids. Though it contains the maximum number of essential amino acids, it creates a problem for those people who are vegetarian, because most of the plant-derived protein do not contain the complete essential amino acid profile. In that case, the Moringa leaf powder could be a good alternative as a source of protein especially for essential amino acids. The 
TABle 2: Proximate profiles of Moringa fresh leaves, dry leaves, and leaf powder.

\begin{tabular}{lccc}
\hline \multirow{2}{*}{ Nutrients } & \multicolumn{3}{c}{ g/100 g plant materials } \\
& Fresh leaves & Dry leaves & Dry leaf powder \\
\hline Protein $(\mathrm{g})$ & 6.7 & 29.4 & 27.1 \\
Fats $(\mathrm{g})$ & 1.7 & 5.2 & 2.3 \\
Carbohydrate $(\mathrm{g})$ & 12.5 & 41.2 & 38.2 \\
Fiber $(\mathrm{g})$ & 0.9 & 12.5 & 19.2 \\
\hline
\end{tabular}

American Dietetic Association and Dieticians of Canada reported that individuals who performed regular physical activities need $1.3 \mathrm{~g}-1.7 \mathrm{~g}$ protein per $\mathrm{kg}$ of body weight to repair body muscles. Table 3 summarizes the protein percentage of total dry matter of different protein sources [28-32].

From the above table, it is clear that Moringa leaves contain a higher amount of protein. It is identified as alternative protein sources which can meet a regular demand of malnourished people [33]. People in many countries consume almost all parts of Moringa oleifera in various ways. Fresh Moringa leaves can be taken through cooking where the leaves can be stored as powder [14]. The seeds are also edible as it is green and dry [34]. However, Moringa leaves contain various types of amino acid. Amino acids such as Thr, Met, Ile, Lys, and Val were found to be present in Moringa leaves which are comparable to meat proteins [22]. Nowadays, Moringa leaf powder is incorporated in various valuable products. Table 4 shows a comparison of the amino acid profiles of conventional animal and plant derived sources with Moringa leaf powder proteins [2, 31, 35].

In leaf source protein, the amino acid profiles are similar in the case of its availability. But the quality varies on the basis of species types, sources of raw materials, plant culture system, harvesting, and processing methods and analysis methods, etc. The miracle Moringa leaves contain 9 essential along with 7 nonessential amino acids. Table 5 disseminates a comparative amino acid profile of Moringa leaf powder with some other consumable leaf powder [29-31].

1.5. Vitamins and Minerals. Besides macronutrients (carbohydrates, protein, and lipids), the animal body requires various micronutrients for survival. These micronutrients are very important for the body which act as a carrier or participate in the breakdown process of macronutrients. Vitamins are important which play a great role in energy processing of the animal body. Beriberi, rickets, scurvy, etc. are very common diseases which occur due to the deficiency of vitamins. Vitamins, such as vitamin A (beta-carotene), vitamin B (folic acid, pyridoxine, and nicotinic acid), vitamin $\mathrm{C}$, vitamin $\mathrm{D}$, and vitamin E, are found in Moringa oleifera [36]. Therefore, Moringa leaf powder or processed food derived from Moringa could be a good source of vitamins. Apart from various vitamins, Moringa contains lot of minerals, which are essential for physiological growth and development. Calcium is considered as one of the most important minerals, where dried Moringa powder is a great source of that element. It possesses 17 times more calcium than milk [22]. Without that, it contains $2 \mathrm{mg} / 100 \mathrm{~g}$ iron and $25.5-31.03 \mathrm{mg} / \mathrm{kg}$ zinc
TABle 3: Protein content in various plant leaves including Moringa.

\begin{tabular}{lc}
\hline Food origin & $\begin{array}{c}\text { Protein content (\% dry } \\
\text { matter) }\end{array}$ \\
\hline Rice & 7.4 \\
Wheat flour & 12.1 \\
Mulberry leaves (Morus alba) & 20.88 \\
Anchote leaves (Coccinia & 21.6 \\
abyssinica) & 18.1 \\
Alfalfa leaves (Medicago sativa) & \\
Moringa oleifera & \\
$\quad$ Fresh leaves & 6.7 \\
$\quad$ Dry leaves & 29.4 \\
$\quad$ Leaf powder & 27.1 \\
\hline
\end{tabular}

[22]. It is well enough to fulfill the daily requirement of zinc in the diet [37]. Table 6 depicts a list of vitamins and minerals found in leaf pods and seeds [24, 38].

1.6. Antioxidants. Normally human body maintains a balance ratio between oxidants and antioxidants. Because of external stresses in daily life, animal body continuously produces reactive oxygen species [39]. To balance the body with these free radicals, antioxidants are produced by the body cells. Any imbalance into these systems is known as oxidative stress. It can occur because of numerous diseases or imbalance in the normal physiological system [40]. In the severe stage, the oxidative stage turns the cell damage into various chronic diseases [41]. Kattappagari et al. [42] reported a positive feedback of antioxidant in such kind of chronic conditions that is preventing of further damages.

In terms of antioxidants, Moringa tree can be contemplated as a great source as it shows a higher production capacity than conventional plant-derived sources. Extracts from Moringa tree are capable of producing multiple types of components.

Table 7 comprises antioxidant activity of Moringa leaf methanolic extracts. Al-Taweel and Al-Anbari reported higher antioxidant activity (21.52\%) which occurs due to its phenolic compound [43]. It is observed that Moringa leaf extract shows antioxidant activity both in vivo and in vitro due to its flavonoids and phenolic content [44, 45]. Methanol and ethanol extracts of $M$. oleifera leaves of Indian origin have the highest antioxidant activity with 65.1 and $66.8 \%$, respectively $[17,46]$. For those antioxidant properties, Moringa leaf powder can ensure protection against oxidative stress [47]. Bennett et al. reported chlorogenic acid, gallic acid, kaempferol and glycoside presence in Moringa leaves [48]. Freeze-dried Moringa leaves also show antioxidant activities [25]. However, for better supply for the consumers, naturally synthesized antioxidants have high demand.

\section{Medicinal Uses}

Moringa oleifera has numerous medicinal effective uses which have long been discerned in both the Ayurvedic and 
TABLe 4: Amino acid profile of different protein sources compared with Moringa leaf powder.

\begin{tabular}{|c|c|c|c|c|c|c|c|c|c|}
\hline \multirow{2}{*}{ Source } & \multicolumn{5}{|c|}{ Animal-derived sources } & \multicolumn{3}{|c|}{ Plant-derived Sources } & \multirow{2}{*}{ MLP* } \\
\hline & Egg & $\mathrm{CB}$ & Rui fish & Pangas fish & Tilapia fish & SB & Rice & WF & \\
\hline \multicolumn{10}{|c|}{ Essential amino acids (g/100 g of dry matter) } \\
\hline Histidine & 2.4 & 4.5 & 0.63 & 0.54 & 0.32 & 2.6 & 0.15 & 0.23 & 2.2 \\
\hline Isoleucine & 6.6 & 3.24 & 0.76 & 0.62 & 0.76 & 5.3 & 0.23 & 0.31 & 4.8 \\
\hline Leucine & 8.8 & 6.4 & 1.43 & 1.14 & 1.49 & 7.7 & 0.50 & 0.69 & 9.2 \\
\hline Lysine & 5.3 & 7.9 & 1.58 & 1.25 & 1.60 & 6.4 & 0.23 & 0.28 & 5.6 \\
\hline Methionine & 3.2 & 2.5 & 0.63 & 0.56 & 0.68 & 1.3 & 0.21 & 0.22 & 1.8 \\
\hline Phenyl-alanine & 5.8 & 3.2 & 0.83 & 0.63 & 0.82 & 5.0 & 0.35 & 0.48 & 6.2 \\
\hline Threonine & 5.0 & 3.7 & 0.87 & 0.68 & 0.9 & 4.0 & 0.22 & 0.30 & 4.2 \\
\hline Tryptophan & 1.7 & - & 0.31 & 0.23 & 0.3 & 1.4 & 0.05 & 0.12 & - \\
\hline Valine & 7.2 & 3.46 & 0.98 & 0.76 & 0.94 & 5.3 & 0.37 & 0.45 & 5.4 \\
\hline \multicolumn{10}{|c|}{ Nonessential amino acids ( $\mathrm{g} / 100 \mathrm{~g}$ of dry matter) } \\
\hline Tyrosine & 4.2 & 3.65 & 0.54 & 0.47 & 0.61 & 3.7 & 0.24 & 0.27 & 4.0 \\
\hline Alanine & - & 4.7 & 2.19 & 1.63 & 2.22 & 5.0 & 0.57 & 0.56 & 6.3 \\
\hline Arginine & 6.2 & 5.8 & 1.24 & 0.99 & 1.28 & 7.4 & 0.48 & 0.44 & 7.4 \\
\hline Asparagine & 11.0 & 7.8 & - & - & - & 1.3 & - & - & - \\
\hline Glutamic acid & 12.6 & 11.2 & 3.46 & 2.58 & 3.5 & 19.0 & 1.30 & 3.54 & 10.7 \\
\hline Glycine & 4.2 & 3.4 & 1.36 & 2.58 & 3.49 & 4.5 & 0.29 & 0.41 & 5.3 \\
\hline Proline & 4.2 & 3.2 & 0.99 & 0.75 & 0.89 & 5.3 & 0.27 & 1.07 & 2.9 \\
\hline Serine & 6.9 & 3.4 & 0.80 & 0.63 & 0.81 & 5.8 & 0.32 & 0.51 & 4.1 \\
\hline Cystine & 2.3 & 1.1 & 0.13 & 0.14 & 0.15 & 1.9 & 0.14 & 0.22 & 0.6 \\
\hline
\end{tabular}

CB: chicken breast; SB: soybean; WF: wheat flour; MLP: Moringa leaf powder. *Amino acid profile of Moringa dried powder was analyzed at the Institute of Technology Transfer and Innovation (ITTI), Bangladesh Council of Scientific and Industrial Research (BCSIR), Dhaka.

TABLE 5: Comparative amino acid profile of different consumable leaf powders with Moringa leaf powder.

\begin{tabular}{|c|c|c|c|}
\hline Source & Anchote leaves (Coccinia abyssinica) & Mulberry leaves (Morus alba) & Moringa leaf powder \\
\hline \multicolumn{4}{|c|}{ Essential amino acids (g/100 g of dry matter) } \\
\hline Histidine & 1.63 & 3.56 & 2.2 \\
\hline Isoleucine & 3.70 & 4.74 & 4.8 \\
\hline Leucine & 5.38 & 6.89 & 9.2 \\
\hline Lysine & 3.80 & 5.30 & 5.6 \\
\hline Methionine & 0.93 & 1.78 & 1.8 \\
\hline Phenyl-alanine & 3.10 & 3.34 & 6.2 \\
\hline Threonine & 3.46 & 4.25 & 4.2 \\
\hline Tryptophan & - & - & - \\
\hline Valine & 4.17 & 5.16 & 5.4 \\
\hline \multicolumn{4}{|c|}{ Nonessential amino acids (g/100 g of dry matter) } \\
\hline Tyrosine & 1.63 & \multirow{2}{*}{11.42} & 4.0 \\
\hline Alanine & 5.58 & & 6.3 \\
\hline Arginine & 4.33 & 4.52 & 7.4 \\
\hline Asparagine & 8.94 & 8.26 & - \\
\hline Glutamic acid & 8.92 & - & 10.7 \\
\hline Glycine & 5.69 & 5.94 & 5.3 \\
\hline Proline & 2.16 & - & 2.9 \\
\hline Serine & 4.39 & 4.2 & 4.1 \\
\hline Cystine & 3.27 & - & 0.6 \\
\hline
\end{tabular}


TABLE 6: The vitamin and mineral compositions of leaves, seeds, and pods.

\begin{tabular}{lccccc}
\hline \multirow{2}{*}{ Nutrients } & \multicolumn{5}{c}{ mg/100 g plant materials } \\
& Fresh leaves & Dry leaves & Powder & Seed & Pods \\
\hline Vitamin B1 & 0.06 & 2.02 & 2.64 & 0.05 & 0.05 \\
Vitamin B2 & 0.05 & 21.3 & 20.5 & 0.06 & 0.07 \\
Vitamin B3 & 0.8 & 7.6 & 8.2 & 0.2 & 0.2 \\
Vitamin C & 220 & 15.8 & 17.3 & $4.5 \pm 0.17$ & 120 \\
Vitamin E & 448 & 10.8 & 113 & $751 \pm 4.41$ & - \\
Calcium & 440 & 2185 & 2003 & 45 & 30 \\
Magnesium & 42 & 448 & 368 & $635 \pm 8.66$ & 24 \\
Phosphorus & 70 & 252 & 204 & 75 & 110 \\
Potassium & 259 & 1236 & 1324 & - & 259 \\
Copper & 0.07 & 0.49 & 0.57 & $5.20 \pm 0.15$ & 3.1 \\
Iron & 0.85 & 25.6 & 28.2 & - & 5.3 \\
Sulphur & - & - & 870 & 0.05 & 137 \\
\hline
\end{tabular}

TABle 7: Antioxidant composition of Moringa oleifera leaf extract [43].

\begin{tabular}{lc}
\hline Parameters & Amount \\
\hline Total flavonoids & $257 \mathrm{mg} / 100 \mathrm{~g}$ quercetin equivalent \\
$\begin{array}{l}\text { Total antioxidant } \\
\text { capacity }\end{array}$ & $1701.8 \mathrm{mg} / 100 \mathrm{~g}$ ascorbic acid \\
Total phenols & equivalent \\
\hline
\end{tabular}

Unani systems [49]. Every part of Moringa oleifera is considered as important elements which have diversified medicinal value. Almost all parts of the Moringa trees have been used as natural medicine. Though Moringa tress extracts are used as a high valued food, besides it has various types of medicinal uses. Abalaka et al. [50] reported many pharmaceutical applications in the treatment of many diseases in the traditional medicinal system. In addition, Moringa aqueous extracts of roots were found significant in anti-inflammatory, antiulcer, and antitumor activities.

2.1. Antimicrobial and Anthelmintic Activities. Extracts from leaf, flower root bark, and stem bark of Moringa oleifera have antimicrobial and anthelmintic properties. Pterygospermin has powerful antibacterial and fungicidal activities [51] found by Das et al. and Rao et al. in the leaf and flower, respectively $[52,53]$. Ethanolic extract of seeds, leaves, and flowers revealed the antimicrobial activity against $E$. coli, $P$. aeruginosa, Enterobacter species, K. pneumoniae, S. aureus, Proteus mirabilis, Salmonella typhi A, Streptococcus, and Candida albicans [54]. Moringa Oleifera flower and leaves have been demonstrated for their anthelmintic activity during several studies [55], for example, ethanolic extracts from Moringa oleifera leaves to inhibit Indian earthworm Pheretima posthuma [56].

2.2. Antiasthmatic Activity. Without showing any adverse effects with $M$. oleifera seed kernel, improvement was observed in the treatment of bronchial asthma patients and also their concurrent respiratory functions [57].

2.3. Anticancer and Antitumor Activity. There is a direct connection of Reactive Oxygen Species (ROS) with cell death. Various environmental stresses lead to excessive production of ROS causing progressive oxidative damage and ultimately cell death [58]. The compounds of the leaves that are held responsible for the anticancer activities are glucosinolates, niazimicin, and benzyl isothiocyanate. "Niazimicin" a bioactive compound from Moringa leaves showed potential anticancer activity [59]. Seven bioactive compounds, namely, 4( $\alpha$-L-rhamnosyloxy)-benzyl isothiocyanate, niazimicin, 3O-( $6^{\prime}$-oleoyl- $\beta$-D-glucopyranoyl $)-\beta$-sitosterol, $\beta$-sitosterol3-O- $\beta$-D-glucopyranoside, niazirin, $\beta$-sitosterol, and glycerol-1-(9-octadecnoate) had been isolated from the ethanol extract of the Moringa seed [60]. Benzyl isothiocyanate has been shown to be linked with cancer. Research showed that BITC causes intracellular ROS, which leads to cell death. This could be one of the reasons for Moringa to be a good anticancer agent [61-63]. Moringa contains an antiaging compound called Zeatin, which is a naturally occurring cytokinin [64] which has antitumor activities, effective against prostate and skin cancers, and is a strong antioxidant. The Moringa leaves also showed a significant cytotoxic effect on human myeloma cell lines [65].

2.4. Antidiabetic and Wound Healing Activity. Moringa is reported as an important element in controlling diabetes. Moringa leaves are reported as a significant agent in reducing blood glucose level immediately after taken [66]. The extracts (aqueous) from Moringa showed significant prohealing actions and a perfect wound healing characteristic [67].

2.5. Cardiac and Circulatory Stimulant and Antidiuretic Activities. The bioactive compound alkaloids from Moringa trees act as a cardiac stimulant [68] which are evident to stabilize blood pressure [60] influence on diuretic activity [13] and reduce fat and cholesterol [69] to prevent hyperlipidemia [70] and reduce serum triglyceride and serum cholesterols [71].

2.6. Analgesic Activity. Different parts of Moringa trees (leaves, pod, roots, etc.) showed analgesic activity. The alcoholic extract of Moringa leaves showed identical analgesic activity which was found through tail immersion method [72]. In another study, methanol extract of $M$. oleifera was tested in frog and guinea pig which showed that the plant (root bark) in both animals has produced significant local anaesthetic activity [73].

2.7. Antipyretic Activity. The antipyretic activity of Moringa was assessed in rats using different extracts (ethanol, petroleum ether, and ethyl acetate etc.) where seed extracts (ethanol and ethyl) showed significant activity [74].

2.8. Hepatoprotective Activity. The characteristics of protection against liver damage are reported about Moringa leaf extracts [75], and they also help in reducing liver fibrosis [76]. 
TABle 8: Medicinal uses of different parts of the Moringa tree.

\begin{tabular}{|c|c|c|}
\hline Parts & Uses & References \\
\hline Leaves & $\begin{array}{l}\text { Generally used for the treatment of asthma, bronchitis, hyperglycemia, dyslipidemia, } \\
\text { flu, heart burn, syphilis, malaria, pneumonia, diarrhea, headaches, scurvy, skin diseases, } \\
\text { eye and ear infections. Also it reduces, blood pressure and cholesterol, and it has anticancer, } \\
\text { antimicrobial, antioxidant, antidiabetic, and antiatherosclerotic properties and it acts as a } \\
\text { neuroprotectant agent }\end{array}$ & {$[3,36],[85-87]$} \\
\hline Seeds & $\begin{array}{l}\text { Moringa seeds used for treating hyperthyroidism, Crohn's disease, antiherpes-simplex } \\
\text { virus arthritis, rheumatism, gout, cramp, epilepsy, and sexually transmitted diseases, and } \\
\text { they also act as antimicrobial and anti-inflammatory agents }\end{array}$ & {$[3,20,33],[88,89]$} \\
\hline Root bark & Used as a cardiac stimulant, antiulcer, and anti-inflammatory agent & {$[89,90]$} \\
\hline Flower & Used as a hypocholesterolemic, antiarthritic agents and can cure urinary problems and cold & {$[88]$} \\
\hline Pods & Had a potential role for the treatment of diarrhea, liver and spleen problems, and joint pain & {$[38]$} \\
\hline
\end{tabular}

TABLE 9: Moringa incorporation in different food products.

\begin{tabular}{|c|c|c|c|}
\hline Product types & Addition & Benefits & References \\
\hline Soup & Alone or with spinach, melon, etc. As ingredient of soup & & {$[91]$} \\
\hline Moringa panner & Panner with extract of Moringa leaves & & {$[92]$} \\
\hline Chocolate & $\begin{array}{c}\text { Moringa leaf powder as extra protein and } \\
\text { fiber agent }\end{array}$ & Increase the protein, fiber, and ash level into & {$[93]$} \\
\hline Biscuits and cakes & $\begin{array}{c}\text { Leaf powder in replacement of a percentage } \\
\text { of flour }\end{array}$ & a satisfying amount & {$[93,94]$} \\
\hline Bread & Fortified with 5\% leaf powder & & {$[84]$} \\
\hline Muffin & $12 \%$ incorporation of leaf powder & & {$[95]$} \\
\hline
\end{tabular}

2.9. Antispasmodic and Antiulcer Effects. Because of the spasmolytic activity of Moringa trees, it is used traditionally to treat gastrointestinal motility disorder [77]. It is also reported that the methanolic extracts from this plant protects gastric lesions [78].

2.10. Other Medicinal Uses. M. oleifera pod constituents have bioactive compounds with anti-inflammatory activity which may contribute to ameliorate the pathogenesis of inflammatory-associated chronic diseases [79].Ovalbumininduced airway inflammation in guinea pigs treated with nbutanol extract from $M$. oleifera seeds showed positive result as an anti-inflammatory agent [80]. Moringa was found to benefit and improve the condition against viral infectivity. Leaf extracts showed selective and potent inhibition of early steps in HIV-1 infectivity [81]. Hydroalcoholic extract of M. oleifera fruits showed antihepatitis B virus (HBV) activity [82]. Moringa is a potential source of vitamin A [83] which has a great potentiality to control the deficiency of vitamin A source food. Rather it could help to reduce eye problems of children.

2.11. Phytochemical Constituents of Moringa oleifera from Different Parts of the Plant. A number of medicinal properties have been described to various parts of this highly esteemed tree (Table 8). Almost all the parts of this plant, root, bark, gum, leaf, fruit (pods), flowers, seed, and seed oil, have been used for various ailments in indigenous medicines [84].

\section{Market Trends}

In recent times, people are aware about health-related issues, and they are very much interested in taking healthy and nutritious food. For instance, food which has a wide range of health benefits may prevent or cure various chronic diseases. This kind of extraordinary food is also termed as super food. It is a new field of research to identify such sources of healthy and nutritious foods.

The global Moringa markets are expected to increase significantly within the near future. According to MRFR analysis report, the global Moringa product field is expected to reach $9.3 \%$ which is USD 7902.9 million by 2025 . Moringa products such as oils, capsules, leaf powder, and soaps are extracted from different parts of the tree. In contrast to the global contribution, the Asia Pacific contributed the largest share of $35.30 \%$ of the Moringa product market in 2018 . Australia, China, India, and New Zealand are key countries which are contributing in the growth. Asia Pacific is the largest producer of Moringa. The production in the region is mostly consumed locally due to the traditional use of Moringa in wellness, skincare, and hair care. The market in North America is expected to register a CAGR of $10.0 \%$ by 2025.

\section{Moringa Incorporation in Various Food Products}

Moringa-derived food and nutraceutical products possess a huge potential which can decelerate the rate of 
malnourishment in developing nations. Some food products incorporated with leaf powder are shown in Table 9.

\section{Risk Factors}

We all know that Moringa is a nutritional miracle tree, but it has some side effects reported by Cadman [96].

(1) For pregnant women: though Moringa leaves alone are enough to satisfy the daily iron and calcium need [22], it may possess antifertility characteristics in some cases

(2) For thyroid treatment: though Moringa leaves aid thyroid function, it may create problems during the treatment with any other thyroid medication

(3) For diabetic medications: though Moringa leaves effectively reduce blood sugar, it may cause too low blood sugar levels in some cases

(4) For blood pressure medication: though Moringa is used in lowering blood pressure, Moringa with drugs that reduce blood pressure may result in a too low blood pressure

\section{Conclusion}

Moringa oleifera is a prominent source of nutrients and antioxidants. Like other vegetables such as spinach and fenugreek, Moringa leaves are not as popular all over the world, but currently, it is used as substitutes in soups, lentils, and other preparations in Southeast Asia. Still there is a knowledge gap in potential uses of Moringa as a food supplement and food fortification. Moringa has enormous potential uses but is very less explored. It can be utilized to make foods that could be a step towards curbing malnutrition. The published literature gives the total scenario of the chemical constituents, nutritional content, potential uses, and pharmacological activities of the plant. The identification, isolation, and standardization of plant extracts may be considered for detailed studies which can be useful for the further development of the promising food products with health benefits and nutrients to cure different life style-related diseases as well as malnutrition.

\section{Data Availability}

Previously reported article, case study, and report, etc. data were used to support this study and are available in the cited references. Only the amino acid values of the Moringa leaf powder amino acids and proximate data were analyzed at the Institute of Technology Transfer and Innovation, BCSIR, under the supervision of the authors. These prior studies (and datasets) are cited at relevant places within the text as references [1-97].

\section{Conflicts of Interest}

The authors declare that they have no conflict of interests.

\section{Acknowledgments}

The authors are grateful to the Bangladesh Council of Scientific and Industrial Research (BCSIR) and the Ministry of Science and Technology, Bangladesh, for funding. This research was supported by the Ministry of Science and Technology, Bangladesh.

\section{References}

[1] "Know your world: facts about world hunger \& poverty," n.d, http://www.thp.org/knowledge-cennter/know-your-worldfacts-about-hunger-poverty.

[2] "FAO-news article: world's future food security "in jeopardy" due to multiple challenges, report warns," n.d., http://www.fao .org/news/story/en/item/471169/icode.

[3] J. L. Rockwood, B. G. Anderson, and D. A. Casamatta, "Potential uses of Moringa oleifera and an examination of antibiotic efficacy conferred by M. oleifera seed and leaf extracts using crude extraction techniques available to under-served indigenous populations," International Journal of Phytothearpy Research, vol. 3, no. 2, pp. 61-71, 2013.

[4] S. Kushwaha, P. Chawla, and A. Kochhar, "Effect of supplementation of drumstick (Moringa oleifera) and amaranth (Amaranthus tricolor) leaves powder on antioxidant profile and oxidative status among postmenopausal women," Journal of Food Science and Technology, vol. 51, no. 11, pp. 3464-3469, 2014.

[5] F. William, S. Lakshminarayanan, and H. Chegu, "Effect of some Indian vegetables on the glucose and insulin response in diabetic subjects," International Journal of Food Sciences and Nutrition, vol. 44, no. 3, pp. 191-195, 1993.

[6] P. Libby, "Inflammation in atherosclerosis," Nature, vol. 420, no. 6917, pp. 868-874, 2002.

[7] K. Ahuja and K. Mamtani, "Moringa ingredients market size by product (seed and oil [by application ffood, cosmetics, water purification\}, by distribution channel \{online, supermarket, retail stores, specialty stores\}], Moringa tea [by distribution channel \{online, supermarket, retail stores, specialty stores\}], leaf powder [by application \{cosmetics, dietary supplement, food\}, by distribution channel \{online, supermarket, retail stores, specialty stores\}]), industry outlook report, regional analysis, application potential, price trends, competitive market share \& forecast, 2019 - 2025,” Global Market Insights, 2019, Report ID: GMI4352.

[8] Prota, "PROTA4U web database. Wageningen, Netherlands: plant resources of tropical Africa," 2017, https://www .prota4u.org/database/.

[9] S. Tak and I. B. Maurya, "Genetic diversity of Moringa oleifera Lam. In Rajasthan, India," Acta Horticulturae, no. 1158, pp. 71-78, 2017.

[10] https://www.zauba.com/import-moringa-oleifera-hs-code .html.

[11] Y. R. S. Gonzalez and E. C. L. J. van der Maden, Opportunities for development of the Moringa sector in Bangladesh; deskbased review of the Moringa value chains in developing countries and end-markets in Europe, no. 15-102, 2015Centre for Development Innovation, Wageningen UR, 2015.

[12] N. Z. Abd Rani, K. Husain, and E. Kumolosasi, "Moringa genus: a review of phytochemistry and pharmacology," Frontiers in Pharmacology, vol. 9, p. 108, 2018. 
[13] J. F. Morton, “The horseradish tree, Moringa pterygosperma (Moringaceae)-a boon to arid lands?," Economic Botany, vol. 45, no. 3, pp. 318-333, 1991.

[14] J. W. Fahey, "Moringa oleifera: a review of the medical evidence for its nutritional, therapeutic and prophylactic properties. Part 1," Trees for Life Journal, vol. 1, no. 5, pp. 1-15, 2005.

[15] M. E. Olson and J. A. Rosell, "Using heterochrony to detect modularity in the evolution of stem diversity in the plant family Moringaceae," Evolution, vol. 60, no. 4, pp. 724-734, 2006.

[16] K. T. Mahmood, T. Mugal, and I. U. Haq, "Moringa oleifera: a natural gift - a review," Journal of Pharmalogical Sciences and Research, vol. 2, no. 11, pp. 775-781, 2010.

[17] P. Siddhuraju and K. Becker, "Antioxidant properties of various solvent extracts of total phenolic constituents from three different agroclimatic origins of drumstick tree (Moringa oleifera Lam.) leaves," Journal of Agricultural and Food Chemistry, vol. 51, no. 8, pp. 2144-2155, 2003.

[18] B. A. Anhwange, V. O. Ajibola, and S. J. Oniye, "Chemical studies of the seeds of Moringa oleifera (Lam) and Detarium microcarpum (Guill and Sperr)," Journal of Biological Sciences, vol. 4, no. 6, pp. 711-715, 2004.

[19] B. Sultana and F. Anwar, "Flavonols (kaempeferol, quercetin, myricetin) contents of selected fruits, vegetables and medicinal plants," Food Chemistry, vol. 108, no. 3, pp. 879-884, 2008.

[20] J. N. Kasolo, G. S. Bimenya, L. Ojok, J. Ochieng, and J. W. Ogwal-Okeng, "Phytochemicals and uses of Moringa oleifera leaves in Ugandan rural communities," Journal of Medicinal Plants Research, vol. 4, no. 9, pp. 753-757, 2010.

[21] M. Busani, J. M. Patrick, H. Arnold, and M. Voster, "Nutritional characterization of Moringa (Moringa oleifera Lam) leaves," African Journal of Biotechnology, vol. 10, no. 60, pp. 12925-12933, 2011.

[22] L. Gopalakrishnan, K. Doriya, and D. S. Kumar, "Moringa oleifera: A review on nutritive importance and its medicinal application," Food Science and Human Wellness, vol. 5, no. 2, pp. 49-56, 2016.

[23] S. Al-Taweel and I. Al-Anbari, "Evaluation of inhibitory efficiency of stevia's extract in microorganisms that cause food spoilage," in 9th International Conference for Sustainable Agricultural Development, Egypt, 2019.

[24] P. T. Olagbemide and P. C. Alikwe, "Proximate analysis and chemical composition of raw and defatted Moringa oleifera kernel," Advances in Life Science and Technology, vol. 24, pp. 92-99, 2014.

[25] B. Uphadek, D. M. Shinkar, P. B. Patil, and R. B. Saudagar, "Moringa oleifera as a pharmaceutical excipient," International Journal of Current Pharmaceutical Research, vol. 10, no. 2, pp. 13-16, 2018.

[26] L. Berkovich, G. Earon, I. Ron, A. Rimmon, A. Vexler, and S. Lev-Ari, "Moringa oleifera aqueous leaf extract downregulates nuclear factor-kappab and increases cytotoxic effect of chemotherapy in pancreatic cancer cells," BMC Complementary and Alternative Medicine, vol. 13, no. 1, pp. 212219, 2013.

[27] G. Wu, "Dietary protein intake and human health," Food and Function, vol. 7, no. 3, pp. 1251-1265, 2016.

[28] E. Christaki, P. Florou-Paneri, and E. Bonos, "Microalgae: a novel ingredient in nutrition," International Journal of Food Sciences and Nutrition, vol. 62, no. 8, pp. 794-799, 2011.
[29] Y. Ayalew, N. Retta, G. Desse, A. Mohammed, and A. Mellesse, "Amino acid profile and protein quality in tuber and leaf of Coccnia abyssinica(Lam.) (Cogn.) accessions of Ethiopia," Food Science and Nutrition, vol. 5, no. 3, pp. 722-729, 2017.

[30] J. Yao, B. Yan, X. Q. Wang, and J. X. Liu, "Nutritional evaluation of mulberry leaves as feeds for ruminants," Livestock Research for Rural Development, vol. 12, no. 2, pp. 9-16, 2000, http://www.cipav.org.co/lrrd/lrrd12/2/yao122.htm.

[31] N. Shaheen, S. Islam, S. Munmun, M. Mohiduzzaman, and T. Longvah, "Amino acid profiles and digestible indispensable amino acid scores of proteins from the prioritized key foods in Bangladesh," Food Chemistry, vol. 213, pp. 83-89, 2016.

[32] H. Fekadu Gemede, W. Merga, M. Dufera, and B. Serbessa, "Nutritional and phenolic profiles of leaves of fifteen anchote (Coccinia abyssinica) accessions," Cogent Food \& Agriculture, vol. 7, no. 1, p. 1911031, 2021.

[33] M. D. Thurber and J. W. Fahey, "Adoption of Moringa oleifera to combat under-nutrition viewed through the lens of the "diffusion of innovations" theory," Ecology of Food and Nutrition, vol. 48, no. 3, pp. 212-225, 2009.

[34] M. R. Berger, M. Habs, S. A. A. Jahn, and D. Schmalhl, "Toxicological assessment of seeds from Moringa oleifera and Moringa stenopetala, two highly efficient primary coagulants for domestic water treatment of tropical waters," East African Medical Journal, vol. 61, no. 9, pp. 712-716, 1984.

[35] D. Pimentel and M. Pimentel, "Sustainability of meat-based and plant-based diets and the environment," The American Journal of Clinical Nutrition, vol. 78, no. 3, pp. 660S-663S, 2003.

[36] M. Mbikay, "Therapeutic potential of Moringa oleifera leaves in chronic hyperglycemia and dyslipidemia: a review," Frontiers in Pharmacology, vol. 3, p. 24, 2012.

[37] J. T. Barminas, M. Charles, and D. Emmanuel, "Mineral composition of non-conventional leafy vegetables," Plant Foods for Human Nutrition, vol. 53, no. 1, pp. 29-36, 1998.

[38] L. J. Fugile, "The Moringa tree: a local solution to malnutrition," Church World Service in Senegal, vol. 5, pp. 75-83, 2005.

[39] V. Hajhashem, G. Vaseghi, M. Pourfarzam, and A. Abdollahi, "Are antioxidants helpful for diseases prevention?," Research in Pharmceutical Sciences, vol. 5, no. 1, pp. 1-8, 2010.

[40] L. A. Pham-Huy, H. He, and C. Pham-Huy, "Free radicals, antioxidants in disease and health," International Journal of Biomedical Sciences, vol. 4, pp. 89-96, 2008.

[41] S. Topdag, A. Aslaner, C. Tataroglu, and Z. Ilce, "Evaluation of antioxidant capacity in lung carcinoma," Indian Journal of Thoracic and Cardiovascular Surgery, vol. 21, pp. 269-271, 2005.

[42] K. K. Kattappagari, C. R. Teza, R. K. Kommalapati, C. Poosarla, S. R. Gontu, and B. V. R. Reddy, "Role of antioxidants in facilitating the body functions: a review," Journal of Orofacial Sciences, vol. 7, no. 2, pp. 71-75, 2015.

[43] S. K. Al-Taweel and I. H. Al-Anbari, "Review article Moringa olifera: a review on the phytochemical screening, proximate analysis, medicinal, nutritional, and plant biostimulants values of its leaves, pods, seeds and roots," Plant Archives, vol. 19, no. 2, pp. 1612-1622, 2019.

[44] J. Verma and N. K. Dubey, "Prospective of botanicals and microbial products as pesticides of tomorrow," Current Science, vol. 76, pp. 172-179, 1999.

[45] K. Z. Khor, V. Lim, E. J. Moses, and N. A. Samad, "The in vitro and in vivo anticancer properties of Moringa oleifera," 
Evidence-Based Complementary and Alternative Medicine, vol. 2018, Article ID 1071243, 14 pages, 2018.

[46] S. Lalas and J. Tsaknis, "Extraction and identification of natural antioxidant from the seeds of the Moringa oleifera tree variety of Malawi," Journal of the American Oil Chemists' Society, vol. 79, no. 7, pp. 677-683, 2002.

[47] M. Wink, "Secondary metabolites from plants inhibiting ABC transporters and reversing resistance of cancer cells and microbes to cytotoxic and antimicrobial agents," Frontiers in Microbiology, vol. 3, p. 130, 2012.

[48] R. N. Bennett, F. A. Mellon, N. Foidl et al., "Profiling glucosinolates and phenolics in vegetative and reproductive tissues of the multi-purpose trees Moringa oleifera L. (horseradish tree) and Moringa stenopetala L," Journal of Agricultural and Food Chemistry, vol. 51, no. 12, pp. 3546-3553, 2003.

[49] M. H. Mughal, G. Ali, P. S. Srivastava, and M. Iqbal, "Improvement of drumstick (Moringa pterygosperma Gaertn.) a unique source of food and medicine through tissue culture," Hamdard Medius, vol. 42, no. 1, pp. 37-42, 1999.

[50] M. E. Abalaka, S. Y. Daniyan, S. B. Oyeleke, and S. O. Adeyemo, "The antibacterial evaluation of Moringa oleifera leaf extracts on selected bacterial pathogens," Journal of Microbiology Research, vol. 2, no. 2, pp. 1-4, 2012.

[51] K. Ruckmani, S. Kavimani, R. Anandan, and B. Jaykar, "Effects of Moringa oleifera Lam on paracetamol-induced hepatoxicity," Indian Journal of Pharmaceutical Science, vol. 60, no. 1, pp. 33-35, 1998.

[52] B. R. Das, P. A. Kurup, P. L. Rao, and R. Narasimha, "Antibiotic principle from Moringa pterygosperma. VII. Antibacterial activity and chemical structure of compounds related to pterygospermin," The Indian Journal of Medical Research, vol. 45, no. 2, pp. 191-196, 1957.

[53] V. A. Rao, P. U. Devi, and R. Kamath, "In vivo radio protective effect of Moringa oleifera leaves," Indian Journal of Experimental Biology, vol. 39, pp. 858-863, 2001.

[54] P. Nepolean, J. Anitha, and R. R. Emilin, "Isolation, analysis and identification of phytochemicals of antimicrobial activity of Moringa oleifera Lam," Current Biotica, vol. 3, pp. 33-39, 2009.

[55] S. B. Bhattacharya, A. K. Das, and N. Banerji, "Chemical investigations on the gum exudate from sajna (Moringa oleifera)," Carbohydrate Research, vol. 102, no. 1, pp. 253-262, 1982.

[56] T. Rastogi, V. Bhutda, K. Moon, K. B. Aswara, and S. S. Khadabadi, "Comparative studies on anthelmintic activity of Moringa oleifera and Vitex negundo," Asian Journal of Research in Chemistry, vol. 2, no. 2, pp. 181-182, 2009.

[57] B. Agrawal and A. Mehta, "Antiasthmatic activity of Moringa oleifera Lam: a clinical study," Indian Journal of Pharmacology, vol. 40, no. 1, pp. 28-31, 2008.

[58] P. Sharma, A. Á. Jha, R. S. Dubey, and M. Pessarakli, "Reactive oxygen species, oxidative damage, and antioxidative defense mechanism in plants under stressful conditions," Journal of Botany, vol. 2012, 26 pages, 2012.

[59] A. P. Guevara, C. Vargas, H. Sakurai et al., "An antitumor promoter from Moringa oleifera Lam," Mutation ResearchGenetic Toxicology and Environmental Mutagenesis, vol. 440, no. 2, pp. 181-188, 1999.

[60] F. Anwar, S. Latif, M. Ashraf, and A. H. Gilani, "A food plant with multiple medicinal uses. A review article," Phytotherapy Research, vol. 21, no. 1, pp. 17-25, 2007.

[61] Y. Nakamura, N. Miyoshi, T. Osawa et al., "Involvement of the mitochondrial death pathway in chemo preventive benzyl isothiocyanate-induced apoptosis," Journal of Biological Chemistry, vol. 277, no. 10, pp. 8492-8499, 2002.

[62] N. Miyoshi, K. Uchida, T. Osawa, and Y. Nakamura, “A link between benzyl isothiocyanate-induced cell cycle arrest and apoptosis: involvement of mitogen-activated protein kinases in the Bcl-2 phosphorylation," Cancer Research, vol. 64, pp. 2134-2142, 2004.

[63] S. Leelawat and K. Leelawat, "Moringa oleifera extracts induce cholangiocarcinoma cell apoptosis by induction of reactive oxygen species production," International Journal of Pharmacognosy and Phytochemical Research, vol. 6, no. 2, pp. 183-189, 2014.

[64] R. C. Dhakar, S. D. Maurya, B. K. Pooniya, N. Bairwa, and M. Gupta, "Moringa: the herbal gold to combat malnutrition," Chronicles of Young Scientists, vol. 2, no. 3, pp. 119-125, 2011.

[65] M. V. S. Parvathy and A. Umamaheshwari, "Cytotoxic effect of Moringa oleifera leaf extracts on human multiple myeloma cell lines," Trends in Medical Research, vol. 2, no. 1, pp. 44-50, 2007.

[66] M. Mittal, P. Mittal, and A. C. Agarwal, "Pharmacognostical and phytochemical investigation of antidiabetic activity of Moringa oleifera lam leaf," The Indian Pharmacist, vol. 6, no. 59, pp. 70-72, 2007.

[67] B. S. Rathi, S. L. Bodhankar, and A. M. Baheti, "Evaluation of aqueous leaves extract of Moringa oleifera Linn for wound healing in albino rats," Indian Journal of Experimental Biology, vol. 44, pp. 898-901, 2006.

[68] U. Eilert, B. Wolters, and A. Nahrstedt, "The antibiotic principle of seeds of Moringa oleifera and Moringa stenopetala," Planta Medica, vol. 42, no. 5, pp. 55-61, 1981.

[69] S. Ghasi, E. Nwobodo, and J. O. Ofili, "Hypocholesterolemic effects of crude extract of leaf of Moringa oleifera Lam in high-fat diet fed Wistar rats," Journal of Ethnopharmacology, vol. 69, no. 1, pp. 21-25, 2000.

[70] M. Ndong, M. Uehara, S. Katsumata, and K. Suzuki, "Effects of oral administration of Moringa oleifera Lam on glucose tolerance in Goto-Kakizaki and Wistar rats," Journal of Clinical Biochemistry and Nutrition, vol. 40, no. 3, pp. 229-233, 2007.

[71] N. Ara, M. Rashid, and M. S. Amran, "Comparison of Moringa oleifera leaves extract with atenolol on serum triglyceride, serum cholesterol, blood glucose, heart weight, body weight in adrenaline induced rats," Saudi Journal of Biological Sciences, vol. 15, no. 2, pp. 253-258, 2008.

[72] N. G. Sutar, C. G. Bonde, V. V. Patil, S. B. Narkhede, A. P. Patil, and R. T. Kakade, "Analgesic activity of seeds of Moringa oleifera Lam," International Journal of Green Pharmacy, vol. 2, no. 2, pp. 108-110, 2008.

[73] M. Bandana, H. N. Khanikor, L. C. Lahon, P. Mohan, and C. Barua, "Analgesic, anti-inflammatory and local anaesthetic activity of Moringa in laboratory animals," Pharmaceutical Biology, vol. 41, no. 4, pp. 248-252, 2003.

[74] V. I. Hukkeri, C. V. Nagathan, R. V. Karadi, and B. S. Patil, "Antipyretic and wound healing activities of Moringa oleifera Lam. in rats," Indian Journal Pharmaceutical Sciences, vol. 68, no. 1, pp. 124-126, 2006.

[75] N. L. Pariand and A. Kumar, "Hepatoprotective activity of Moringa oleifera on antitubercular drug-induced liver damage in rats," Journal of Medicinal Food, vol. 5, no. 3, pp. 171-177, 2002.

[76] A. A. Hamza, "Ameliorative effects of Moringa oleifera Lam seed extract on liver fibrosis in rats," Food and Chemical Toxicology, vol. 48, no. 1, pp. 345-355, 2010. 
[77] A. H. Gilani, K. Aftab, A. Suria et al., "Pharmacological studies on hypotensive and spasmolytic activities of pure compounds from Moringa oleifera," Phytotherapy Research, vol. 8, no. 2, pp. 87-91, 1994.

[78] S. K. Pal, P. K. Mukherjee, and B. P. Saha, "Studies on the antiulcer activity of Moringa oleifera leaf extract on gastric ulcer models in rats," Phytotherapy Research, vol. 9, no. 6, pp. 446-463, 1995.

[79] C. Muangnoi, P. Chingsuwanrote, P. Praengamthanachoti, S. Svasti, and S. Tuntipopipat, "Moringa oleifera pod inhibits inflammatory mediator production by lipopolysaccharidestimulated RAW 264.7 murine macrophage cell lines," Inflammation, vol. 35, no. 2, pp. 445-455, 2012.

[80] S. G. Mahajan, A. Banerjee, B. F. Chauhan, H. Padh, M. Nivsarkar, and A. A. Mehta, "Inhibitory effect of nbutanol fraction of Moringa oleifera Lam. seeds on ovalbumin-induced airway inflammation in a guinea pig model of asthma," International Journal of Toxicology, vol. 28, no. 6, pp. 519-527, 2009.

[81] C. S. Nworu, E. L. Okoye, G. O. Ezeifeka, and C. O. Esimone, "Extracts of Moringa oleifera Lam. showing inhibitory activity against early steps in the infectivity of HIV-1 lentiviral particles in a viral vector-based screening," African Journal of Biotechnology, vol. 12, no. 30, pp. 4866-4873, 2013.

[82] W. Waiyaput, S. Payungporn, J. Issara-Amphorn, T. Nattanan, and N. Panjaworayan, "Inhibitory effects of crude extracts from some edible Thai plants against replication of hepatitis $\mathrm{B}$ virus and human liver cancer cells," BMC Complementary and Alternative Medicine, vol. 12, no. 1, pp. 1-7, 2012.

[83] V. S. Nambiar, K. Bhadalkar, and M. Daxini, "Drumstick leaves as source of vitamin A in ICDS-SFP," The Indian Journal of Pediatrics, vol. 70, no. 5, pp. 383-387, 2003.

[84] C. E. Chinma, J. O. Abu, and S. N. Akoma, "Effect of germinated tigernut and Moringa flour blends on the quality of wheat-based bread food process," Journal of Food Procesing and Preservation, vol. 38, no. 2, pp. 721-727, 2014.

[85] O. S. Ijarotimi, O. A. Adeoti, and O. Ariyo, "Comparative study on nutrient composition, phytochemical, and functional characteristics of raw, germinated, and fermented Moringa oleifera seed flour," Food Science and Nutrition, vol. 1, no. 6, pp. 452-463, 2013.

[86] I. L. Jung, "Soluble extract from Moringa oleifera leaves with a new anticancer activity," PLoS One, vol. 9, no. 4, pp. 1-10, 2019.

[87] M. K. Choudhary, S. H. Bodakhe, and S. K. Gupta, “Assessment of the antiulcer potential of Moringa oleifera root-bark extract in rats," Journal of Acupuncture and Meridian Studies, vol. 6, no. 4, pp. 214-220, 2013.

[88] C. Sutalangka, J. Wattanathorn, S. Muchimapura, and W. Thukham-mee, "Moringa oleifera mitigates memory impairment and neurodegeneration in animal model of agerelated dementia," Oxidative Medicine and Cellular Longevity, vol. 2013, 9 pages, 2013.

[89] T. G. Monera and C. C. Maponga, "Prevalence and patterns of Moringa oleifera use among HIV positive patients in Zimbabwe: a cross-sectional survey," Journal of Public Health Africa, vol. 3, pp. 6-8, 2012.

[90] O. S. Adeyemi and T. C. Elebiyo, "Moringa oleifera supplemented diets prevented nickel-induced nephrotoxicity in Wistar rats," Journal of Nutrition and Metabolism, vol. 2014, 8 pages, 2014.
[91] A. Babayeju, C. Gbadebo, M. Obalowu et al., "Comparison of Organoleptic properties of egusi and eforiro soup blends produced with Moringa and spinach leaves," Food Science and Quality Management, vol. 28, pp. 15-18, 2014.

[92] P. Sachan, B. L. Khan, M. P. S. Yadav, and S. Sonkar, "Effect of drumstick leaves extraction the nutritional quality of Moringa paneer prepared from different blend of cow milk and leaves extract," Progressive Agriculture, vol. 10, no. 1, pp. 98-101, 2010.

[93] A. A. Abou-Zaid and A. S. Nadir, "Quality evaluation of nutritious chocolate and Halawa Tahinia produced with Moringa (Moringa oleifera) leaves powder," Middle East Journal of Applied Sciences, vol. 4, no. 4, pp. 1007-1015, 2014.

[94] M. Alam, M. Hakim, H. Abdul, A. Obidul, and S. Moktadir, "Development of fiber enriched herbal biscuits: a preliminary study on sensory evaluation and chemical composition," International Journal of Nutrition and Food Science, vol. 3, pp. 246250, 2014.

[95] S. Srinivasamurthy, U. Yadav, S. Sahay, and A. Singh, "Development of muffin by of dried Moringa oleifera (drumstick) leaf powder with enhanced micronutrient content," International Journal of Food Science and Nutrition, vol. 2, no. 4, pp. 173178, 2017.

[96] B. Cadman, "What makes Moringa good for you," Medical News Today, 2020.

[97] O. O. Odebiyi and A. E. Sofowora, "Pytochemical screenings of Nigerian medicinal plants part II," Lloydia, vol. 44, no. 3, pp. 234-246, 1978. 